\title{
Todo iba bien. Breve ensayo sobre la tristeza, la nostalgia y la felicidad
}

\author{
Autor / Author \\ DÍAZ, Itoxu
}

Editorial / Publishing company

ENCUENTRO, Madrid 2020

Este ensayo de Itxu Díaz no ha podido ser más oportuno. Todo iba bien, o lo bien que pueden ir las cosas cuando cada uno de nosotros se encuentra inmerso en una rutina más o menos aceptable, hasta que una pandemia golpea a la humanidad entera. La COVID-19 no ha entendido de fronteras, posición social, razas, religiones..., ha convulsionado al mundo. El escritor había terminado este ensayo, epílogo incluido, cuando se vio sorprendido, como todos nosotros, por «el drama del coronavirus» (p. 182). Es entonces cuando añade las últimas páginas: «El año sin primavera», un capítulo que sirve de colofón para mostrar que ningún ser humano está exento de sufrimiento, enfermedad o miedo, y, menos aún, que puede burlar a la muerte. Si alguna persona se había sentido invencible, marzo de 2019 ha sido un baño de realidad: todos somos finitos, vulnerables..., y en esa debilidad se nos invita a buscar una respuesta sobre el sentido de la vida.

Comenzaba esta reseña comentando la oportunidad del texto, todavía hubiera resultado más conveniente haber tenido este libro en los duros meses del confinamiento. Su lectura sosegada, las cuestiones que el mismo Itxu se hace en primera persona y sobre las que va profundizando a lo largo de los capítulos se convierten en la ocasión para ahondar en nuestro interior e intentar también dar una respuesta. El aislamiento domiciliario es un buen momento para la introspección. Nunca tenemos tiempo, o no queremos tenerlo, para dedicarlo a plantearnos en serio las cuestiones profundas de la vida. El ser humano, inmerso en las prisas y los ruidos, pretende resolver sus carencias sin querer mirarlas antes a la cara. Itxu frena, Itxu reflexiona, Itxu escribe, Itxu propone y nos enfrenta con un misterio que cuesta digerir: «Todas las salas y antesalas de la tristeza que hemos recorrido en las páginas precedentes se han presentado de golpe en nuestro mundo, frente a la realidad de una vida que, pese al espejismo, nunca nos ha pertenecido del todo. Un recordatorio como una losa: la última palabra sobre la muerte no la tiene la 
ciencia, una vez más, sino Dios» (p. 182). Una reflexión final que, tal vez, no sea posible si previamente la persona no se reconoce como un ser finito.

A lo largo del ensayo, constatamos algo que la propia experiencia vital nos ha enseñado: no estamos preparados para sufrir. Añoramos la felicidad, una felicidad sin límites, una vida plena en compañía de todas las personas a las que amamos. Díaz descubre a una edad temprana que hasta el mes de agosto se puede tornar triste, melancólico. Tras el fallecimiento de su abuelo comprende que «no estamos preparados para la tristeza. No sabemos casi nada del dolor, que es una realidad casi más grande que la vida. Y sin embargo, lo enfrentamos, lo sobrevivimos, lo sobrellevamos» (p. 14).

Ante el dolor, la enfermedad, el sufrimiento, el ser humano intenta reinventarse para poder sobrellevar el trago amargo del mal. La duda es si esa forma de resignación, de estoicismo no acentúa todavía más, si cabe, nuestra tristeza y la nostalgia por los tiempos pasados. Parece que «somos fáciles de engañar. Nuestra soberbia intelectual es la premisa. Y el problema del dolor, la insatisfacción y el legítimo anhelo de una vida plena, se encargan de hacer el resto del trabajo cuando alguien pone en tus manos las páginas para una solución rápida, infalible y gratuita» (p. 19). Estamos dispuestos a "comprar» cualquier solución para que el sufrimiento pase, pero caemos nuevamente en la desolación cuando vemos que no es tan fácil ni tan sencillo curar nuestra alma. Nos encontramos perdidos, sin saber escapar del callejón sin salida, no sabemos encontrar la felicidad, el Ave Fénix es un espejismo. Las soluciones que se nos proponen son efímeras, parciales y parecen no dar una respuesta completa a lo que buscamos: «Nuestro interior nos impulsa también a buscar el bien, la alegría, la verdad, la felicidad y la belleza. [...] El bien nos llena. Lo bello nos colma» (p. 21). Pero aunque buscamos esa felicidad no sabemos dónde hallarla y, como dijo Pascal, solo encontramos muerte.

No es propio de Itxu Díaz el dramatismo. Sus escritos están salpicados de pinceladas de humor que provocan la sonrisa e invitan a seguir animadamente con la lectura. Todo iba bien, pese a ser un ensayo sobre la tristeza y la nostalgia, como reza su título, también lo es sobre la felicidad. Para contribuir a ello, con un agudo ingenio, Itxu no renuncia a su sentido del humor y a la crítica irónica: "A los hedonistas del siglo xxı les resultaría muy interesante comprobar que quien mejor puede apreciar la felicidad es quien ha tenido también la experiencia de la privación, el silencio y el sufrimiento, como quienes padecieron mil tormentos en aquellos campos de concentración» (p. 26). El dolor, por paradójico que parezca, permite al ser humano gozar de las experiencias gratificantes de la vida. Y, a veces, aquel que es más insoportable, una vez superados los momentos más duros, capacita para disfrutar de la vida en un sentido más pleno. Itxu invita a redescubrir algo totalmente olvidado en nuestra cultura: valorar el sentido pedagógico del sufrimiento en vez de «despojarlo de toda buena fama que en tiempos anteriores pudo lucir» (p. 26).

A lo largo del ensayo se muestran claves al lector para que descubra que, aunque a veces la realidad pueda parecer insoportable, la vida tiene sentido: «El bien compensa con creces el mal» (p. 38). Todo apunta a que ese sentido es difícil descubrirlo aquí y ahora, a la par que «toda nuestra racionalidad y nuestro universo sensorial se rebelan contra cualquier foco del sufri- 
miento» (p. 65). Algo en nuestro interior nos conduce a pensar que el final no puede ser la muerte, el mal no puede tener la última palabra. Toda nuestra naturaleza se rebela ante el paso del tiempo que nos acerca a la desaparición de este mundo, ni siquiera nos basta con que nos recuerden los nuestros porque ellos también dejarán de existir algún día. Terrible pesadilla la del ser humano que se enfrenta en soledad y con las manos vacías al final de sus días.

Y entonces llegó el epílogo: «Dios está aquí». El lado oscuro del dolor invita a buscar la luz. El darse cuenta de la vulnerabilidad y de la finitud de la naturaleza humana guía a «algo» superior que dé sentido a la existencia sufriente. Surge la pregunta por Dios. Ahora bien, un Dios como consuelo racional «creado» por el hombre para aliviar la tristeza tampoco es la solución. Solo cuando en el silencio de la noche, en la sociedad profunda, en aquel recoveco del alma donde nadie puede entrar, el hombre se descubre incondicionalmente amado. Es entonces cuando puede alzar los ojos hacia arriba, postrarse de rodillas y abandonarse al Dios consolador y misericordioso. Y por ello, «la tristeza es siempre estación de paso» (p. 180).

\section{MIRÓ LÓPEZ, Susana}

Profesora doctora de Formación Humanística Universidad Francisco de Vitoria Madrid (España) 